5. Лучин В. О., Мазуров А. В. Новый закон о референдуме // Право и политика. 2004. № 8. С. 6.

6. Нудненко Л. А. Законодательство о выборах и референдумах: детализация и совершенствование // Российский юридический журнал. 2009.№ 1.С. 178.

7. Пастухова Н. В. Правовые ограничения инициирования, назначения и проведения референдума в Российской Федерации: понятие и система // Государство и право. 2010. № 10. С. 112, 115.

8. Турищева, Н. Ю. Преступления против избирательных прав и права на участие в референдуме / Н.Ю. Турищева. - М.: Издательство Р. Асланова "Юридический центр Пресс", 2010. - 352 с.

\title{
Скопенко О.P. \\ Наследственный фонд: зарубежный опыт и перспектива развития в России
}

Белгородский государственный нацииональный исследовательский университет (НИУ «БелГУ»)

(Россия, Белгород)

doi: $10.18411 / \mathrm{sr}-10-10-2017-18$

idsp: 000001:sr-10-10-2017-18

\section{Аннотация}

Статья посвящена нововведениям в российское наследственное законодательство, а именно, введению с 01сентября 2018 года новой формы юридического лица Наследственного фонда. В ней освещены проблемы, связанные с реализацией этого нового инструмента управления бизнесом в случае смерти владельца, создаваемого в исполнении его завещания.

Автор, опираясь на многовековую историю создания и существования частных фондов, как в Америке, так и в странах Европы, сходных по признакам правовой формы, но различных по целям и характеру деятельности, определяет преимущества и недостатки создания и существования Наследственного фонда в России. Дается понятие Наследственного фонда, выделяются основные аспекты положений о новом правовом институте, особенности его формирования и функционирования в России.

Ключевые слова: наследники, завещание, частный фонд, траст, Наследственный фонд, бенефициары.

Институт наследования в Российском праве всегда занимал и продолжает занимать особое место. Если говорить об истоках его возникновения, то это произошло еще несколько тысяч лет назад с появлением частной собственности. Однако все большую актуальность вопросы наследования приобретают в современном мире. И связано это тесным образом с развитием бизнеса.

Если обратиться к современной России, то она существенно отличается от времен СССР социальным расслоением, когда разделение на «богатых и бедных» увеличивается с огромной скоростью. Все больше граждан создают свой успешный бизнес и пытаются управлять им, зарабатывая достаточные капиталы, которые состоят из различных активов. Это и денежные средства в разных валютах, ценные бумаги, недвижимость, корпоративные права участия, интеллектуальная собственность и т.д. В связи с этим возникает логичный вопрос: «Как грамотно распорядиться этим капиталом, чтобы сохранить его и приумножить достигнутое?». Особенно этот вопрос становится актуальным при передаче капитала приемникам. Поэтому главной проблемой российского наследственного права, которую необходимо решить на сегодняшний день, является отсутствие механизма управления бизнесом в случае смерти владельца, если не предусмотрен порядок завещания.

В связи с этим Государственной Думой был принят Федеральный закон от 29.07.2017 № 259-Ф3 «О внесении изменений в части первую, вторую и третью Гражданского кодекса Российской Федерации », которым с 01 сентября 2018 года вводится новая форма юридического лица - Наследственный фонд. Возникает интерес, 
какие функции будет нести это новое образование, каковы его преимущества и недостатки?

Прежде чем обратиться к регулированию данного вопроса в отечественном праве, с одной стороны, необходимо учесть многовековую историю создания и существования частных фондов, как в Америке, так и в странах Европы, сходных по признакам правовой формы, но различных по целям и характеру деятельности.

За границей практика создания подобных фондов существует уже давно. Они создаются бизнесменами и очень богатыми людьми еще при жизни. Целью создания таких фондов за рубежом является не только поддержка после своей смерти родственников, но и возможность приносить пользу обществу, направляя средства фонда на благотворительность. Самым известным примером такой благотворительности может служить фонд Нобеля.

С другой стороны, не стоит отрицать неоднозначного отношения многих стран к созданию подобных частных фондов. Так, некоторые из них, например Франция и, что немаловажно, до недавнего времени и Россия, отрицательно относились к их созданию. В то время как другие, например, такие как Германия, Лихтенштейн, Нидерланды, напротив, допускают создания частных фондов, причём нет принципиальной разницы между способом создания такого фонда, наследственным, созданным по завещанию и иными фондами. Если допускается создание частных фондов, то нет причин для того, чтобы разрешить их создание по завещанию, но запретить при жизни или наоборот.

В странах континентально-европейского права частные фонды являются аналогом английского траста, который впервые появился еще в XI веке. Передача имущества бенефициарам через такой институт в средние века стала активно использоваться как альтернатива завещанию и средство против налога на наследство.

Если говорить с точки зрения корпоративного права, то фонд, в отличие от корпоративных организаций, не имеет членства. Бенефициары частного фонда, вообще говоря, юридически не имеют влияния на управление фондом, например не могут своим волеизъявлением сместить руководство фонда, пренебрегающее интересами бенефициаров.

Соответственно, работоспособность частных фондов зависит от наличия в данной юрисдикции достаточно высокой культуры управления активами. В противном случае юридическая конструкция фонда может стать источником злоупотреблений руководителей фонда по отношению к выгодоприобретателям. В публичных фондах надзор за руководящими органами ложиться на государственные органы, как правило, специально для этого созданными. Что же касается частных фондов, то эта задача ложится на судебную систему. Таким образом, эффективность управления частными фондами в основном зависит от независимости судебной системы и наличия богатой судебной практики в области фидуциарного управления активами, а также от предоставляемых данным правопорядком возможностей раскрытия в ходе судебного разбирательства всей информации о деятельности руководства фонда.

Что касается вещного права, то правовая конструкция частного фонда, подобно правовой конструкции английского частного траста, в некотором смысле расщепляет классическую триаду права собственности (владение, распоряжение, использование). Владение и распоряжение имуществом осуществляется фондом, а выгоды от использования имущества, по сути, принадлежат бенефициарам. В связи с этим возникает множество вопросов о природе, характере и объеме прав бенефициара на имущество фонда.

В англо-американской правовой системе выработали определенный подход по отношению к трастам. Суть его заключается в следующем: « Если у бенефициара есть определенный интерес к имуществу, подлежащий судебной защите, то на этот интерес можно обратить взыскание по иску кредитора бенефициара. Если интерес бенефициара 
имеет слишком отдаленный или умозрительный характер, то этот интерес не поддается экономической оценке, а потому на него нельзя обратить взыскание».

Что же касается российского законодательства, то фонд рассматривается как некоммерческая организация, которая ставит перед собой «благотворительные, культурные, образовательные или иные социальные, общественно полезные цели». Федеральным законом от 29.07.2017 № 259-Ф3 определяется понятие Наследственного фонда, условия, цели и задачи его возникновения и существования.

Согласно принятым поправкам Наследственным фондом признается фонд, создаваемый во исполнение завещания гражданина и на основе его имущества. Основная деятельность фонда направлена на управление полученным в порядке наследования имуществом этого гражданина бессрочно или в течение определенного срока. Неотъемлемой частью завещания, условия которого предусматривают создание наследственного фонда, являются решение завещателя об учреждении Наследственного фонда, разработка устава фонда, а также определение условий управления фондом. При принятии такого решения завещатель также определяет порядок, размер, способы и сроки образования имущества фонда, лиц, назначаемых в состав органов данного фонда и порядок определения таких лиц. Наследственный фонд подлежит созданию после смерти завещателя по заявлению, которое нотариус, ведущий наследственное дело, направляет в уполномоченный государственный орган. В этой бумаге нужно указать имя гражданина или компании, которые будут управлять фондом. Таким образом, всё наследуемое имущество сразу после смерти владельца аккумулируется в новом правовом институте. Из этих активов или из доходов от их управления можно будет производить выплаты тем лицам, которых владелец состояния указал в завещании. Получателями таких денег могут быть не только физические лица, но и целые компании - все зависит от воли самого наследодателя.

К заявлению прилагаются решения об учреждении фонда и утверждении устава фонда, составленные при жизни гражданина - завещателя. Устав наследственного фонда и условия управления им нельзя изменить, за исключением случая, когда выгодоприобретатель признается недостойным наследником (ст. 1117 ГК). Наследственный фонд призывается к наследованию по завещанию после его создания.

Таким образом, новый закон все полномочия по учреждению фонда после смерти гражданина, основываясь на завещании наследодателя, передает нотариусу. В связи с этим, недоработкой законодателя представляется тот факт, что от этих важных действий отстраняется исполнитель завещания. Согласно внесенным поправкам он может лишь обратиться в суд, если нотариус нарушил законодательство. Между тем, если завещатель назначил исполнителя завещания, то, видимо, ему он доверял больше, чем нотариусу.

Стоит обратить внимание на следующие основные аспекты новых положений о Наследственном фонде РФ. Среди них:1) расширение сферы наследования по завещанию; 2) учредителем выступает исключительно одно физическое лицо; 3) создание Наследственного фонда происходит только после смерти наследодателя; 4) Наследственный фонд РФ является юридическим лицом и обладает признаками этого субъекта права; 5) целевое использование имущества, переданного фонду.

В новеллах наследственного права распоряжение о создании Наследственного фонда рассматривается как неотъемлемая часть завещания. Вместе с тем, представляется, что распоряжение завещателя о создании Наследственного фонда является самостоятельным способом распоряжения имуществом на случай смерти. Обращая внимание на преимущества и недостатки создания Наследственного фонда, стоит отметить, что решение наследодателя о создании фонда предопределяет особенный порядок распределения наследственной массы и иную судьбу имущества, передаваемого фонду. В данном случае, волеизъявление наследодателя о создании фонда и передаче фонду наследственной массы может ограничивать реализацию прав наследников по закону, включая и право на обязательную долю. Наследники, даже и участвующие в 
последующей деятельности фонда, уже не становятся непосредственными обладателями права собственности на объекты наследственного имущества. Также подразумевается и ограниченное целевое использование имущества, переданного фонду, напротив прежнего, как правило, неограниченного обладания и распоряжения объектами наследования со стороны наследников. Таким образом, при возникновении нового субъекта права, каким является Наследственный фонд, вещные правоотношения наследования трансформируются в обязательственные правоотношения по участию в управлении Наследственным фондом или приобретению имущества от фонда.

Другим недостатком рассматриваемой нормы можно отметить доктринальный подход РФ, согласно которому в завещании могут содержаться распоряжения только одного гражданина. Совершение завещания двумя или более гражданами не допускается. Российское законодательство по- прежнему не предусматривает среди правовых средств договорного наследования такие распространённые в мире институты как совместное завещание или наследственный договор.

С другой стороны, уникальность новой формы юридического лица Наследственного фонда - состоит в его раздельном существовании от учредителя - уже умершего наследодателя. В таком учреждении отсутствует лицо, которое является собственником наследственного имущества, переданного фонду. Таким образом, Наследственный фонд, являясь искусственной конструкцией и порождением правопорядка высокой ступени развития, самостоятельно существует в обществе вне принадлежности и вне зависимости от воли определённого физического лица.

В поправках, внесенных в Гражданский кодекс РФ Федеральным законом от 29.07.2017 №259-Ф3, предполагается так же, что Наследственный фонд не обязан преследовать публичные общественно полезные цели, а может передавать свое имущество частным лицам (выгодоприобретателям) (п. 3 ст. 123.20-1). Таким образом, законодатели осуществили довольно радикальную реформу законодательства о юридических лицах, впервые введя в российское право частные фонды, т.е. создаваемые для интересов частных лиц.

Само по себе желание наследодателя учредить Наследственный фонд и тем самым облагодетельствовать конкретных частных лиц, как правило своих родственников, вопросов, конечно, не вызывает. Однако для эффективного функционирования частных фондов система правосудия должна обладать рядом характеристик. К ним относятся следующие: 1) наличие у участников гражданского оборота культуры фидуциарного управления активами; 2) наличие у судов квалификации и технических возможностей по справедливому разрешению споров между фидуциариями и их бенефициарами; 3) наличие в правопорядке разумных правил относительно возможности обращения взыскания к бенефициару на его бенефициарный интерес; 4) наличие у судов квалификации и технических возможностей по справедливому разрешению споров по поводу претензий кредиторов бенефициаров в отношении имущества, находящегося в управлении.

Если считать, что такие предпосылки имеются, т.е. что следует допустить создание в России частных фондов, то совершенно необъяснимым выглядит то решение, которое предложено в законопроекте: все новшества относительно частных выгодоприобретателей относятся исключительно к Наследственному фонду. Авторы проекта почему-то считают недопущение смешивания наследственных денег и денег живых людей важной политико-правовой задачей. Во всяком случае, они запрещают внесение дополнительного имущества в Наследственный фонд другими лицами (п. 1 ст. 123.20-1).

В связи с проблематичностью концепции частного фонда многие европейские правопорядки не допускают создания частных фондов. Имеются ли достаточные предпосылки для их введения в России - большой вопрос. 
При отсутствии упомянутых предпосылок частные фонды неизбежно станут неиссякаемым источником злоупотреблений как руководителей фондов против выгодоприобретателей, так и выгодоприобретателей фондов против своих кредиторов.

$$
\text { *** }
$$

1. Гражданский кодекс Российской Федерации (часть третья) от 26.01. 2001 №146-Ф3 (ред. от. 28.03.2017)//Собрание законодательства РФ. - 2001. - №49. - Ст.4552.

2. Налоговый кодекс Российской Федерации от 5 августа 2000 г. №117-Ф3. Часть вторая (ред. от 13.04.2016 г.) // Собрание законодательства РФ. -2000. -№32. -Ст.3340.

3. Федеральный закон от 29.07.2017 N 259-Ф3 О «внесении изменений в части первую, вторую и третью Гражданского кодекса РФ: Федеральный закон от 29.07.2017 N 259-Ф3// URL: http://www.pravo.gov.ru (дата обращения 03.09.2017)

4. Карташов М. А. Общество с ограниченной ответственностью. Историко - правовой аспект.// Санкт Петербург: Издательский дом СпбГУ. - 2012. -с. 41 - 43.

5. Цуканова Е.Ю., Скопенко О.Р. Основания и механизмы отстранения от наследства недостойных наследников//Теория и практика современной России: сборник научных трудов международной научно-практической конференции. - 2016. - с.99-102. 